\title{
SEGMENTATION OF THE EU COUNTRIES IN TERMS OF THE SHEEP PRODUCTION
}

\author{
Tomasz Rokicki ${ }^{1}$, PhD, habil.; Marcin Ratajczak ${ }^{2}$, PhD \\ 1,2 Warsaw University of Life Sciences
}

\begin{abstract}
The main objective of the studies was to recognize changes taking place in sheep population on the country level in the European Union with special consideration of differentiation present before, during and after the economic crisis the climax of which took place in 2009. Studies have been performed on group included all the countries which belonged to the EU as of 31.12.2013, these were 28 Member States. Data assumed for studies concerned years 2007-2013. In the years 2007-2013, the periods of stabilization (2007-2008), economic crisis (2009-2010) and economy reconstruction (2011-2013) took place that allowed to observe changes as a consequence of stronger stimuli. The sources of the materials were literature, data and statistical analyses from EUROSTAT and FAMU/FAPA. For the purposes of the analysis of the materials, authors used segmentation methods: Ward's method, k-Means, logistic regression model based on the so-called cumulative logits, Random Forests, Gradient Boosting. For materials presentation, authors used descriptive, tabular and graphical methods. Studies carried out allowed to show specific mechanisms of agricultural activity relocation and factors which influence on it. Sheep farming measured with the sheep population was subject to gradual relocation from the countries of the highest agricultural as well as social and economic development to the areas less developed within the scope was confirmed.
\end{abstract}

Key words: segmentation of countries, EU countries, sheep production, sheep population.

JEL code: F15, O11, Q10

\section{Introduction}

Sheep farming is the activity of diversified importance in the given countries of the European Union, however with dominating meat performance. Without a detailed analysis it is easy to find information about countries which maintain the biggest sheep population. There are not, however, more extensive studies which would present the types of changes which take place in the sheep farming and their reasons. In the given countries, there are analyses performed on the situation in the national sheep farming, as e.g. in the work of Rokicki, Gruszecki and Szymanowska (2014), without, however, sufficient studies concerning all countries of the EU. There are comparisons of situations in a few neighbouring countries available which have similar specificity of sheep farming but the analysis refers to comparison in pairs as e.g. in the article of Weglarzy and Skrzyzala (2012) on Poland and Slovakia. More advanced studies are rarely carried out. An example may be the work of Montossi and others (2013). The problem of insufficient consideration in the analysis of sheep farming is especially present in the countries which maintain small sheep population. Poland is an example as there are not many researchers who deal with economic aspect of sheep farming here.

Sheep farming in the countries of the EU is carried out with the use of many sheep species and in various environmental conditions. Sheep are very plastic animals which can adjust to extreme environmental conditions (Rokicki, 2015, 2016). In the analysis, however, only those factors which were connected with agriculture, sheep farming as well as social and economic factors were taken into account. In the studies, the importance of social and economic factors is often neglected as e.g. in the article of M. Smigla (2013) but there are some significant dependencies between them and the production. The market of sheep meat in the EU is not balanced and shortages are observed. Moreover, in the years 2007-2013 the reductions of production were noted so as of the meat consumption. The level of self-supply increased, although still it was lower than $90 \%$. Such a situation leads to the fact that sheep farming in many countries may be developed as on the 
market there is still demand for lamb. The import of frozen meat of worse quality than the one obtained in the EU was necessary.

Primitively, it was also though that there are only a few factors that influence on the region (country) and market development. The opinion was shared by researchers starting from Thünen (1826), Launhardt (1882), Weber (1914). With subsequent studies, the list of factors increased (Marshall (1890), Christaller (1966), Lösch (1954)) and finally, for the purposes of the analysis, apart from agricultural and economical parameters also social variables were accepted (Isard, 1956; Boudeville, 1972). Attention was paid to infiltration and mutual stimulation of the factors what, as a consequence, leads to both, agricultural as well as social and economic development (Myrdal and Sitohang, 1957). Attention was also paid to the relations between the countries of various development level. The most intensive production was at first focused in the most developed countries and areas while the extensive one in the least economically developed ones. The levelling of differences caused that in the developing countries, new technologies were gradually introduced what shortened the distance between the areas of various development levels (Prebisch, 1948). According to the author, the location of the activity is not set for ever. As a result of changes in the factors which influence on it, relocation or delocalisation of many business activities take place.

\section{Materials and methods}

The main objective of the studies was to recognize changes taking place in sheep population on the country level in the European Union with special consideration of differentiation present before, during and after the economic crisis the climax of which took place in 2009.

The following detailed objectives have been assumed in the work:

- classification of countries into homogenous segments in which sheep farming determined by sheep population was explained with the use of selected groups of variables,

- recognition of the impact of short-term economic prospects on the segmentation of countries before, during and after the economic crisis.

One hypothesis was stated in the work:

sheep farming measured with sheep population was subject to gradual relocation from countries of the highest level of agricultural as well as social and economic development to the areas which were less developed within the scope.

Studies have been performed on group included all the countries which belonged to the EU as of 31.12.2013, these were 28 Member States. Data assumed for studies concerned years 2007-2013. Such a period was selected for studies due to two basic premises. In the years 2007-2013, sheep meat and sheep farming market was not subject to regulations which could involve the preference of specific countries or groups of countries. Even before special bonuses for manufacturers which decided to keep the mother sheep in the countries of the old EU have no longer been paid what allowed for creating fair competition conditions in the activity for all countries in the EU. In the studies, the impact of agricultural policy concerning directly sheep farming was limited then. Such a situation allowed to determine the factors which influenced on the sheep population in the European Union whilst eliminating the impact of agricultural policy. The other premise was the occurrence of the economic crisis in the studied period which influenced on various aspects of economic activity including agriculture and sheep farming. In the years 2007-2013, the periods of stabilization (2007-2008), economic crisis (2009-2010) and economy reconstruction (2011-2013) 
took place what allowed to observe changes as a consequence of stronger stimuli. Moreover, the impact of the economic crisis caused that the dependencies have been more visible than in the conditions of economy and agriculture stabilisation.

The sources of the materials were:

- national and foreign literature,

- secondary data from EUROSTAT and FAMU/FAPA,

- statistical analyses published by EUROSTAT.

The following were used for the purposes of the analysis of the materials:

- segmentation method (Ward's method, k-Means, logistic regression model based on the socalled cumulative logits, Random Forests, Gradient Boosting).

In Ward's method, the results were presented in the form of a connection tree. The distance of Euclid was used as the base distance (Ward, 1963; de Amorim, 2015). In all the segmentation methods, for the purposes of evaluating the group uniformity the statistical Hosking-Wallis test was applied. In the model, the variability of indicators calculated from L-moments ratio with the 'expected' variability for homogenous groups are compared. L-moments are more resistant to disorders than normal moments and this is why they are often used while studying problems when the normality of distributions cannot be assumed (Hosking and Wallis, 1993, 1997; Castellarin et al., 2008).

Methods for materials presentation:

- descriptive, tabular, graphical.

Because of the fact there were no references in literature, the analysis was carried out with the use of a few methods, and the most appropriate one was selected based on both, econometric and expert's premises. The segmentation of the EU countries was realized taking into account six methods. The authors analysed one dependent variable - sheep population. The variable was measured on the ratio (continuous) scale, which made it difficult to compare the impact of other variables. This is why, for the purposes of the analysis, the variable was subject to discretizing growth transformation to 5 classes (20-percentage percentiles).

In order to select the best segmentation of countries, assumptions have been made which should be observed for sheep population. There are at least two countries of the biggest sheep population which come from the countries of the so-called EU-15, so from among Great Britain, France and Spain in one segment. The assumptions were verified for the periods with regard to which segmentation was performed. The presented classification allowed for separating the group of countries of the highest importance in sheep farming in the EU.

\section{Research results and discussion}

In the work, countries were divided into homogenous groups in which the level and changes of sheep farming were explained by means of agricultural variables and social and economic indicators. 


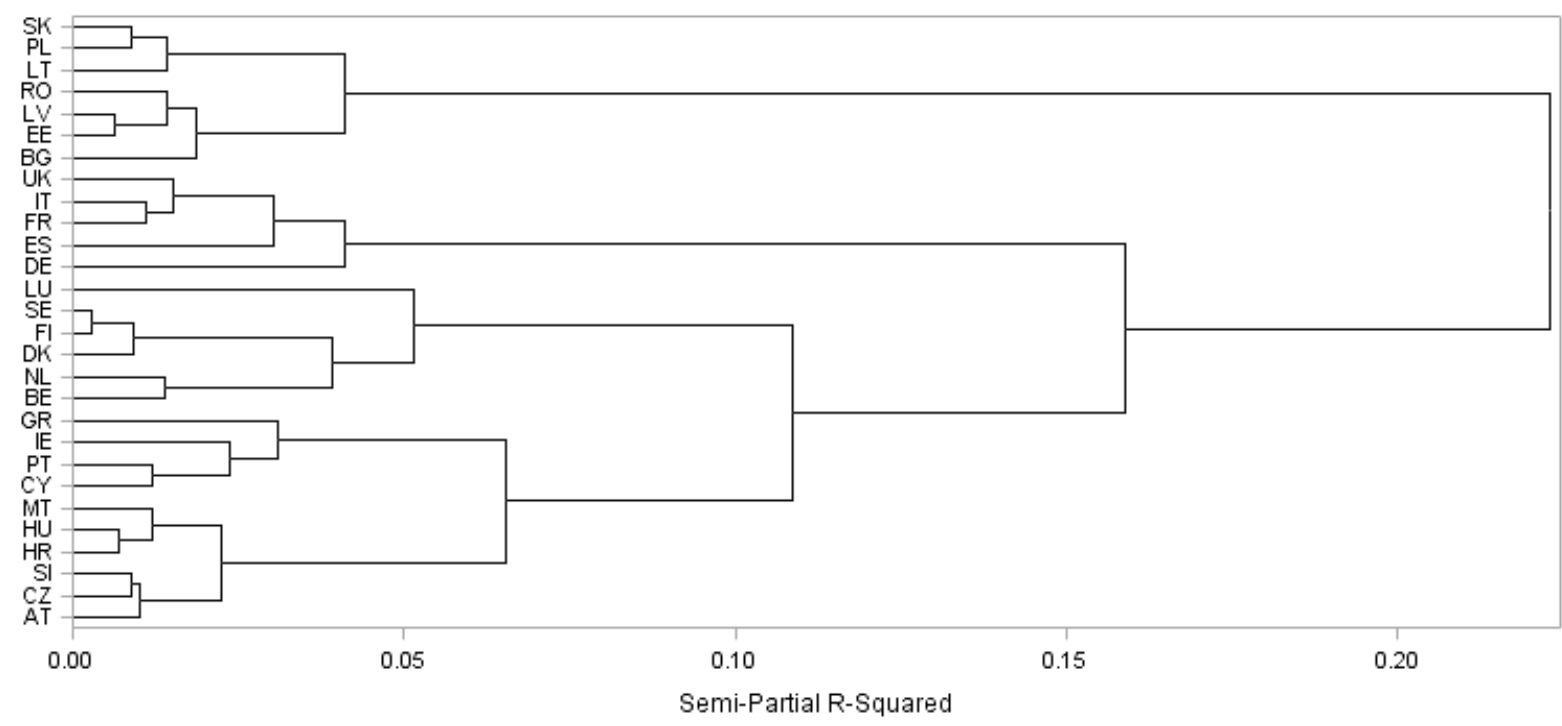

Source: authors' elaboration

Fig. 1. Hierarchical tree for country classification by the Ward method into unified groups of variables in the field of agriculture and socio-economic affecting the sheep population in 2007-2013

\section{Segments of countries in classification by the Warda method into unified groups of variables in the field of agriculture and socio-economic affecting the sheep population in 2007-2013}

\begin{tabular}{|l|l|}
\hline Segments of countries & \multicolumn{1}{|c|}{ Countries } \\
\hline Group I (CL12) & Austria, Croatia, Czech Republic, Malta, Slovenia, Hungary \\
\hline Group II (CL6) & France, Spain, Germany, Great Britain, Italy \\
\hline Group III (CL9) & Cyprus, Greece, Ireland, Portugal \\
\hline Group IV (CL5) & Belgium, Denmark, Finland, Netherlands, Luxembourg, Sweden \\
\hline Group V (CL7) & Bulgaria, Estonia, Lithuania, Latvia, Poland, Romania, Slovakia \\
\hline
\end{tabular}

Source: authors' elaboration

For the entire 2007-2013 period, there were clear links between countries, and the distances were not large (Figure 1). Five segments were distinguished, which were presented on the map (Figure 2). One segment includes countries with the largest sheep populations, such as Spain, France, Great Britain, but also Germany and Italy. The individual groups were also well focused taking into account geographical distribution. Detailed breakdowns into groups of countries are presented in Table 1. Countries, that were included in particular segments, were analysed together by providing the average value per country for particular variables concerning agriculture and the socio-economic situation (Table 2). For all the study periods, segmentation of countries made by Ward's method was the best (Figure 2). In the period of recovering after the economic crisis, the biggest differences in the countries which keep sheep in the EU was present. The analysis of the segmentation of countries confirms strong relationships between sheep production and changes of agricultural parameters as well as social and economic features. Before and during the economic crisis the same countries with the biggest sheep population from Western Europe belonged to one group. In the years 2011-2013, Germany belonged to a separate group due to the sheep population forming factors which influence on sheep meat production what confirms the validity for separate segmentation for subsequent periods. Bigger differences in the groups were also present. In the years 2007-2008, sheep population increased in the countries which specialized in the 
production, of high sheep population while it decreased in the countries with small sheep population; however, the changes in sheep farming were slight. During the crisis (2009-2010), the situation in sheep population depended on the agricultural as well as social and economic stability, the reductions took place in bad situations while the growths in good ones. Similar dependencies took place in the years 2011-2013. So, gradual relocation of sheep farming from developed countries but countries having problems, to developing ones with stable economic situation took place. The most important indicator for the development of national sheep farming was then the situation agricultural and social and economic stability. 
Intra-class average of selected agricultural and socio-economic variables determining sheep population in EU countries in 2007-2013

\begin{tabular}{|c|c|c|c|c|c|c|}
\hline \multirow{2}{*}{ Parameters } & \multicolumn{5}{|c|}{ Average results for groups of countries } & \multirow{2}{*}{$\begin{array}{c}\text { Average } \\
\text { EU }\end{array}$} \\
\hline & $\mathbf{I}$ & II & III & IV & $\mathbf{V}$ & \\
\hline $\begin{array}{l}\text { Share of grassland in agricultural land } \\
(\%)\end{array}$ & 30 & 37 & 42 & 26 & 28 & 31 \\
\hline $\begin{array}{l}\text { Share of agricultural land in total area } \\
(\%)\end{array}$ & 53 & 59 & 44 & 42 & 49 & 50 \\
\hline Number of cattle per 100 ha of UAA & 47 & 49 & 51 & 102 & 19 & 53 \\
\hline Number of dairy cows per 100 ha of UAA & 17 & 12 & 11 & 29 & 9 & 16 \\
\hline Number of sheep per 100 ha of UAA & 31 & 55 & 130 & 15 & 16 & 42 \\
\hline $\begin{array}{l}\text { Export of agricultural products } \\
\text { (EUR million) }\end{array}$ & 3341 & 34292 & 4170 & 17199 & 3570 & 12013 \\
\hline $\begin{array}{l}\text { Import of agricultural products } \\
\text { (EUR million) }\end{array}$ & 3543 & 38065 & 4937 & 13716 & 3293 & 12024 \\
\hline $\begin{array}{l}\text { Value of sheep meat production } \\
\text { (EUR million) }\end{array}$ & 14 & 502 & 130 & 14 & 41 & 124 \\
\hline $\begin{array}{l}\text { Value of sheep meat production (EUR per } \\
\text { capita) }\end{array}$ & 2.00 & 8.87 & 18.87 & 121 & 3.07 & 5.73 \\
\hline $\begin{array}{l}\text { Share of the followers of Judaism in } \\
\text { society }(\%)\end{array}$ & 0.1 & 0.3 & 0.1 & 0.2 & 0.1 & 0.2 \\
\hline $\begin{array}{l}\text { Share of the followers of Islam in society } \\
(\%)\end{array}$ & 1.8 & 4.7 & 8.1 & 4.0 & 2.1 & 3.8 \\
\hline $\begin{array}{l}\text { Professionally active in agriculture } \\
\text { according to the share in the population }\end{array}$ & 2.1 & 1.4 & 4.7 & 1.3 & 5.0 & 2.9 \\
\hline Milk yield of cows (litres) & 5660 & 6654 & 5168 & 7586 & 4718 & 5944 \\
\hline $\begin{array}{l}\text { Consumption of mineral fertilizers (kg per } \\
1 \text { ha of UAA) }\end{array}$ & 127 & 96 & 85 & 130 & 67 & 101 \\
\hline Sheep meat consumption (kg per person) & 0.8 & 2.7 & 6.3 & 1.2 & 0.9 & 2.0 \\
\hline Total meat consumption (kg per person) & 83 & 88 & 84 & 82 & 64 & 79 \\
\hline Pork meat consumption (kg per person) & 45 & 41 & 36 & 35 & 36 & 39 \\
\hline Poultry meat consumption (kg per person) & 21 & 23 & 23 & 20 & 20 & 21 \\
\hline Beef meat consumption (kg per person) & 13 & 19 & 17 & 23 & 6 & 15 \\
\hline Population (thousands of people) & 5929 & 63158 & 6759 & 8044 & 11155 & 18027 \\
\hline Area of the country $(\mathrm{km} 2)$ & 55492 & 389896 & 75024 & 149093 & $\begin{array}{c}12658 \\
5\end{array}$ & 155828 \\
\hline GDP value (EUR million) & 107215 & 1851403 & $\begin{array}{c}14687 \\
7\end{array}$ & 308923 & 94888 & 464485 \\
\hline GDP per capita (EUR) & 17488 & 28797 & 24429 & 45048 & 9388 & 24380 \\
\hline Budget deficit by share in GDP & -3.74 & -4.68 & -8.41 & -0.90 & -3.44 & -3.89 \\
\hline Public debt by share in GDP & 58.20 & 80.01 & 97.08 & 49.44 & 29.30 & 58.54 \\
\hline $\begin{array}{l}\text { Gross value added of agriculture } \\
\text { (EUR million) }\end{array}$ & 1358 & 20235 & 2466 & 2814 & 2685 & 5531 \\
\hline Household consumption (EUR million) & 60628 & 1051538 & 90573 & 142133 & 57676 & 258581 \\
\hline Household consumption (EUR per capita) & 9243 & 16440 & 14111 & 19076 & 5524 & 12401 \\
\hline
\end{tabular}

Source: authors' elaboration 

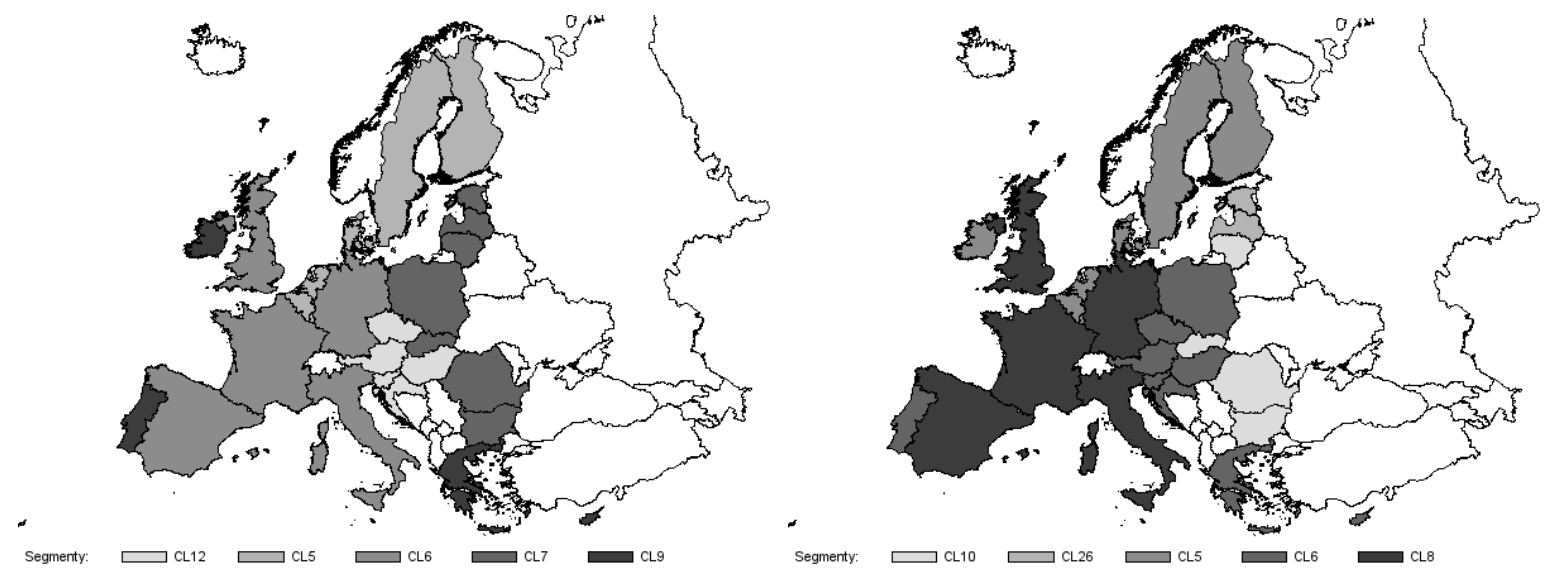

2007-2013

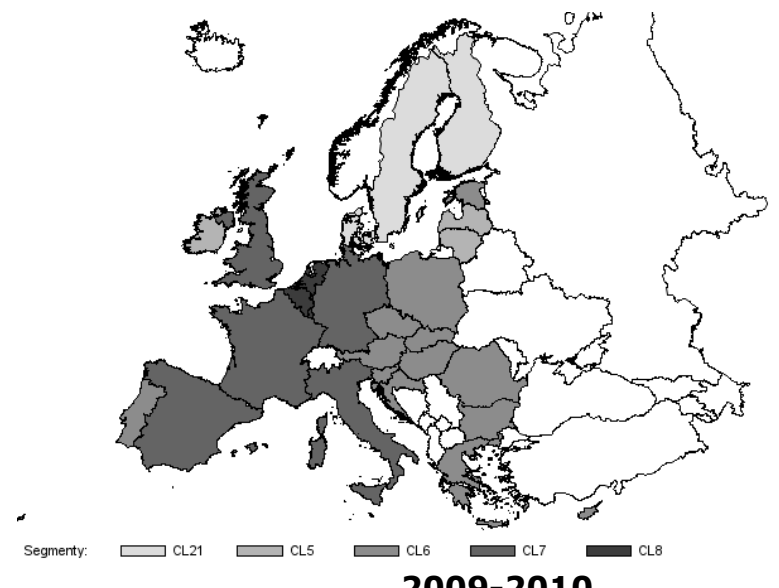

2009-2010

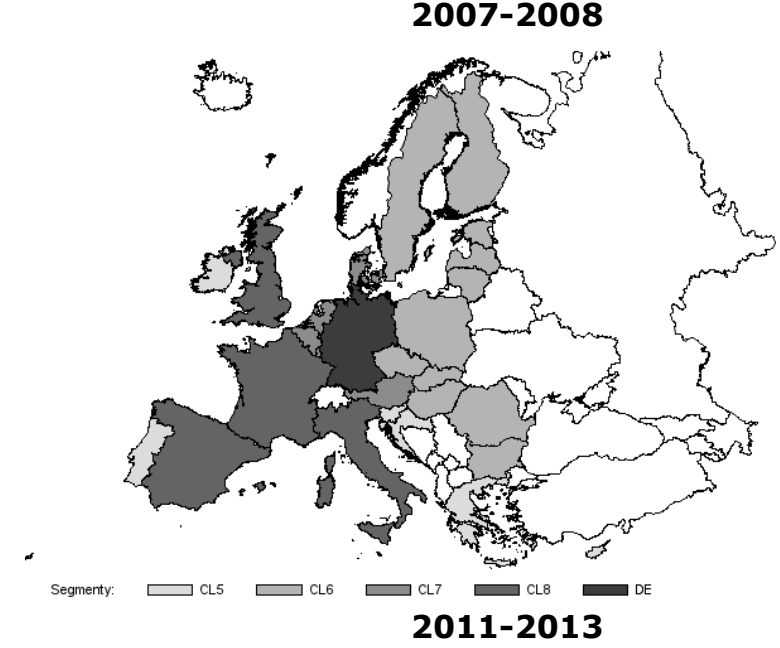

Source: authors' elaboration

Fig. 1. Classification of countries by the Ward method into unified groups of variables in the field of agriculture and socio-economic affecting the sheep population in 2007-2013 (in periods 2007-2013, 2007-2008, 2009-2010, 2011-2013)

\section{Conclusions}

1) Based on the empirical studies presented in the work, some generalisations and conclusions have been formulated. Studies carried out allowed to show specific mechanisms of agricultural activity relocation and factors which influence on it. The total transfer of sheep farming will never take place as sheep farming on some areas does not have any competition, as e.g. in the very high parts of the mountains. It was also stated that in the centres with longterm tradition of breeding, the quantity of sheep was decreased as e.g. in Spain. In turn, sheep population was increased in the countries which maintained a small number of sheep and which had not been traditional places for their breeding as e.g. Lithuania, Latvia and the Czech Republic.

2) In the studies, the hypothesis according to which sheep farming measured with the sheep population was subject to gradual relocation from the countries of the highest agricultural as well as social and economic development to the areas less developed within the scope was confirmed. In terms of the countries, the biggest sheep population was still in the most developed countries in which big regional differentiation was present and sheep farming was taking place on the areas of lower level of development. 


\section{Bibliography}

1. Boudeville, R. J. (1972). Amenagement du territoire et polarisation (Land-Use Planning and Polarization). Paris.

2. Christaller, W. (1966 (1933)). Central Places in Southern Germany, translation by C. W. Baskin. PrenticeHall, Inc., 1, Englewood Cliffs, II.J.

3. de Amorim, R.C. (2015). Feature Relevance in Ward's Hierarchical Clustering Using the Lp Norm, Journal of Classification, Volume 32, Issue 1, pp. 46-62.

4. Hosking, J. R. M. Wallis, J. R. (1993). Some Useful Statistics in Regional Frequency Analysis, Water Resources Research Volume 29, Issue 2, pp. 271-281.

5. Hosking, J. R. M. Wallis, J. R. (1997). Regional Frequency Analysis - an Approach Based on L-moments. Cambridge University Press, New York, p. 224.

6. Castellarin, A. Burn, D. H. Brath, A. (2008). Homogeneity Testing: How Homogeneous do Heterogeneous Cross-Correlated Regions Seem? Journal of Hydrology, Volume 360, Issue 1, pp. 67-76.

7. Isard, W. (1956). Location and Space-Economy. MIT Press, Cambridge, Massachusetts.

8. Launhardt, W. (1882). Die Bestimmung des Zweckmassigsten Standortes einer Gewerblichen Anlage (The Determination of the Most Appropriate Location of a Commercial Facility), Zeitschrift des Vereines Deutscher Ingenieure, 26(3), pp. 105-116.

9. Lösch, A. (1954 (1944)). The Economics of Location, translation by W. H. Waglom, Yale Universitv Press, New Haven.

10. Marshall A., (1890). Principles of Economics, Macmillan and Co. Ltd., London.

11. Montossi, F., Font-i-Furnols, M., Del Campo, M., San Julian, R., Brito, G., Sanudo, C. (2013). Sustainable Sheep Production and Consumer Preference Trends: Compatibilities, Contradictions, and Unresolved Dilemmas. Meat science, 95(4), pp. 772-789.

12. Myrdal, G. Sitohang, P. (1957). Economic Theory and Under-Developed Regions, London.

13. Prebisch, R. (1948). Estudio económico de América Latina (Economic Study of Latin America), Cepal, Santiago de Chile.

14. Rokicki, T., Gruszecki, T. M.,Szymanowska, A. (2014). Economic Performance of Sheep Farms by Example of Lublin Province, Annales of The Polish Association of Agricultural and Agribusiness Economists, Vol. 16, No 3, pp. 254-258.

15. Rokicki, T., (2015). Economic Results of Sheep Farms in Poland, Economic Science for Rural Development, Economic Science for Rural Development. Proceedings of the International Scientific Conference, No 37, pp. 86-92.

16. Rokicki, T., (2016). Sustainable Development in Energy Sector in the European Union Countries, Economic Science for Rural Development. Proceedings of the International Scientific Conference, No 43, pp. 108-116.

17. Śmigla, M. (2013) Zroznicowanie gospodarstw mlecznych FADN w regionach Unii Europejskiej w 2009 roku (Diversification of FADN Dairy Farms in Regions of the European Union in 2009). Roczniki Ekonomiczne Kujawsko-Pomorskiej Szkoły Wyższej w Bydgoszczy, (6), s. 375-386.

18. Von Thunen, J. H. (1826). Der Isolierte Staat in Beziehung auf Landwirtschaft und Nationalökonomie (The Isolated State in Relation to Agriculture and National Economy). Hamburg, Perthes.

19. Ward, J. H. (1963). Hierarchical Grouping to Optimize an Objective Function, Journal of the American Statistical Association, 58, pp. 236-244.

20. Weber, A. (1914). Indrustrielle Standortslehre: reine und kapitalistische Theorie des Standorts (Theory of the Location of Industries). Grundriss der Socialökonomik, VI B, Tübingen, pp. 54-82.

21. Weglarzy, K. Skrzyzala, I. (2012). Porownanie owczarstwa krajowego z owczarstwem w Slowacji (Comparison of National Sheep Production with Production in Slovakia). Przegląd Hodowlany, 3-4, s. 16-18 